\title{
Internal Quality Assurance Management To Improve Graduate Absorption
}

\author{
Ulfiah $^{1)}$, Wiwik Dyah Ariyani ${ }^{2}$, Hanafiah $^{3)}$, Fitriyani Kosasih ${ }^{4) *}$ \\ ${ }^{1)}$ Vice Chancellor IV of UIN Sunan Gunung Djati Bandung \\ ${ }^{2,4)}$ Postgraduate School, PAI Management Study Program, UNINUS Bandung \\ ${ }^{3)}$ Postgraduate School, Education Study Program, UNINUS Bandung \\ *Coresponding Author \\ Email : bundabimbim99@gmail.com
}

\begin{abstract}
This research is motivated by the inability of Vocational School to guarantee the academic quality of its graduates according to the National Education Standards). The method used in this research is a case study method. The results showed that: 1) Planning (Plan) was in accordance with school quality planning procedures, but they still did not understand the stages of quality assurance. 2) In its implementation (Do) there are still State Vocational High Schools that have not formed an Education Quality Assurance Team for Education Units. 3) Monitoring and evaluation in State Vocational Schools has been carried out but quality audit activities are not carried out procedurally by quality auditors. 4) State Vocational High Schools have compiled corrective actions that are outlined in the Work Plan and School Budget and made based on the results of monitoring and evaluation. 5) Almost all State Vocational High School graduates already have a competency certificate from the Professional Certification Institute-P1, but the percentage of State Vocational High School graduates who get a job within one year after graduation only reaches 50\%.6) The obstacle faced is the lack of understanding and awareness of the Principal in improving student academic quality assurance. The solution for State Vocational Schools is to implement a quality assurance system model in stages, systematically and continuously. The conclusion of this study is that in principle, State Vocational Schools have implemented a quality management system but have not succeeded.
\end{abstract}

Keywords: Management, Education Quality Assurance, Absorption of Vocational High School Graduates

\section{INTRODUCTION}

This research is motivated by several problems, including: 1) There is an imbalance between the main mission of vocational secondary education to prepare graduates to be ready to enter the world of work as stated in Government Regulation No. 66 of 2010, with the fact that the contributors to the Highest Unemployment Rate are Vocational School graduates. In 2018-2019 Vocational School graduates contributed 11.39\% to unemployment, this figure was the highest number compared to other education levels. 2) There is an imbalance in the output of SMK graduates. It is stated in the Guidelines for the National Accreditation of Schools/Madrasah that within 1 year after graduation, $75 \%$ of Vocational School graduates are already working/entrepreneurs. However, the facts on the ground show that within 1 year after graduation, on average only $50 \%$ of SMK graduates are working/entrepreneurs. 3) It is stated in Government Regulation No.19 of 2005 Article 19 that all educational units are required to carry out quality assurance. However, based on the results of the 2021 Vocational School accreditation, of the 106 accredited only $3 \%$ are accredited A, 36\% are accredited B, $49 \%$ are accredited $\mathrm{C}$, and $13 \%$ are not accredited.

Thus, it can be concluded that more than $50 \%$ of Vocational School have not met the National Education Standards and have not implemented a quality assurance system on an ongoing basis. Therefore, an effort is needed to improve the quality of Vocational School graduates through academic quality assurance in the Deming cycle covering aspects of Plan, 
Do, Check, Act (PDCA) which are carried out by the internal education unit consistently, systematically and continuously.

One approach that can be used as a reference to improve the implementation of the quality assurance system is to implement the W. Edwards Deming Education Quality Assurance System model, namely the PDCA (Plan, Do, Check, Action) cycle. implementing a quality assurance system as a systematic and continuous cycle. Schools are expected to be able to plan quality fulfillment based on quality mapping through school self-evaluation and quality report cards, carry out quality compliance, monitor and evaluate quality fulfillment results, and develop quality improvement actions/strategies based on monitoring and evaluation results, so that schools can plan for quality fulfillment again. if the expected results have not been achieved or develop a new strategy to improve the fulfillment of the quality of the results of the competence of graduates achieved. This is as quoted by Nanang Fattah (2016: 37) in the Education Quality Assurance System, namely; There are four aspects in the education quality assurance cycle including Plan, Do, Check, Action;

1) Plan (Planning) is a plan related to quality planning, including the determination of quality policy, determination of quality objectives and indicators of their achievement, as well as determination of procedures and achievement of quality objectives.

2) Do (Implementation) is the implementation of what has been planned, so to ensure the quality of education, the entire educational process, including educational administration services is carried out in accordance with the SOP (Standard Operational Procedure) that has been determined.

3) Check (Monitoring and Evaluation) is the existence of monitoring, checking, measuring and evaluating the implementation and results of implementation, including internal quality audits.

4) Action is the follow-up and improvement of the evaluation results, namely the preparation of quality improvement strategies.

Edward Deming stated that "quality is conformance to market or consumer needs. Companies must really be able to understand what consumers need for a product to be produced" (Nasution, 2010: 128). Deming was the one who popularized its use and expanded the application of PDCA (Plan, Do, Check, Act). PDCA is also known as the "Shewhart Cycle", because it was first proposed by Walter Shewhart several decades ago. But in its development, the PDCA analysis methodology is more often called the "Deming Cycle". When it comes to fixing low quality, Deming recommends 'starting by knowing what the customer wants and designing production methods and products to the highest standards'. (Sallis, 2011: 9). Meanwhile (Nasution, 2010:121) stated that; The PDCA cycle is the application of the concept of quality control and to get maximum results, quality control must be carried out to the maximum as well, by applying the principles of maximum quality control. Applying the principles of maximum quality control requires steps at each stage, including:

1. Planning stage (Plan)

a. It must be determined which processes need improvement, namely processes that are closely related to the organization's mission and customer demands.

b. Determine what improvements will be made to the selected process. Determine the data and information needed to select the process that is most relevant to the company.

2. Implementation stage (Do)

a. Gather basic information about the ongoing process.

b. Make the desired changes to be implemented, by adjusting the existing real conditions, so as not to cause turmoil.

c. Back to collect data to find out whether the changes have brought improvement or not. 
3. Check stage. Interpret changes by compiling the data that has been collected in a graph. Graphics are commonly used in quality control, namely analyzing, summarizing and interpreting data and information to get conclusions.

4. Corrective action stage (Action) Deciding which changes will be implemented, if the changes made are successful for improvement.

The quality assurance system is the result of the internal and external demands of vocational education to improve its quality. Sani (2015) stated that "The quality assurance system is the development of the concept of quality assurance that seeks to create a culture by encouraging all members of the organization to be able to satisfy learners or external stakeholders".

Quality assurance is a system that has goals, benefits and stages that are used as a guide to the implementation of vocational education. The objectives of education quality assurance according to Sani (2015) are improving the quality of education services, improving the productivity and efficiency of education through improving school performance, and improving the quality of performance in an effort to result in graduates who satisfy and meet the needs of stakeholders. As for the purpose of quality assurance according to Yorke (1997) in Saputra (2007); The purposes of assurance of these qualities include the following:

1. Help continuous and continuous improvement and improvement through best practices and innovation.

2. Making it easy to get help, whether a money loan or a facility or other assistance from a powerful clan institution is trustworthy.

3. Provide information to the public according to goals and times consistently, and when possible, compare the standards that have been achieved with the standards of competitors.

4. Guaranteeing there will be no unwanted things. In addition, the purpose of this quality assurance is to be able to satisfy various parties involved in it, so that it can successfully achieve their respective goals.

Based on the above understanding can be interpreted that quality assurance management is the management of quality standard fulfillment activities, implemented as a system that contains values and principles in the process of change, improvement, and quality development consistently, systematically and sustainably.

Research related to quality assurance of education, previously conducted by Rifai (2014), in the Journal entitled Development of quality assurance model of vocational high school education. Journal of Management Accountability. Vol. 9, No. The result of this research is that $\mathrm{s}$ Vocational School's internal quality assurance model needs to be developed with components of quality standard setting, determination of quality standard operating procedures, implementation-monitoring, evaluation of quality standards and 45 components of improvement as a unit with the aim to meet educational quality standards.

Asnaul Lailina Zahrok, (2020:17). In the Journal entitled Implementation of internal quality assurance system in Vocational High School. Journal of Accountability of Education Management. Vol 8, No.2. The results of the study showed that quality assurance in Vocational School 35 Tulungagung began from the School Self-Evaluation to obtain quality achievement mapping from every aspect of the National Standard of Education. Quality achievements that are felt less are further improved through continuous quality fulfillment. Quality fulfillment efforts are planned by the School Education Quality Assurance Team as outlined in the form of quality fulfillment planning documents. 
The purpose of this research is to describe and analyze the planning, implementation, monitoring and evaluation and remedial action/follow-up implementation of academic quality assurance management, graduate absorption, as well as obstacles and solutions in graduates of SMKN 9 and SMKN 13 Bandung based on the Deming cycle education quality assurance cycle (PDCA).

\section{RESEARCH METHODS}

This research uses a qualitative approach with case study methods. That is, the data collected is not in the form of number data, but derived from interview manuscripts, field records, personal documents, records or memos of researchers and other official documents that support. The purpose of using a qualitative approach is so that researchers can describe the empirical reality behind the phenomena that occur related to Academic Quality Assurance Management in increasing the absorption of graduates in depth, detail and complete.

In this study researchers matched empirical reality with applicable theory using case study methods. This penelitian focuses intensively on one particular object as a case, according to the main elements that must be found and in accordance with the focal points of the problem, the purpose of the research, and the benefits of research. Yin (2003) also defines; "Case studies as a method of conducting a study of phenomena that occur with a focus on a person's life experience (real life context), when there is a gap between the environment and the existing context, or when using multiple source evidences"

Data collection techniques are carried out by observation, interview and documentation studies. Field records are made systematically and structured, recordings are done both audioly and visually, and conduct studies on other documents related to academic quality assurance management in increasing the absorption of graduates in SMKN 9 and SMKN 13 Bandung City. As Nana Syaodih Sukmadinata (2009) states that "in qualitative writing the usual data collection techniques are interviews, observations, documentary studies, and literature studies". Strengthened by Sugiyono (2012), states that "in qualitative writing data collection is done in natural settings, primary data sources and data collection techniques are more on participating observations, in-depth interviews, and documentation". In the interests of data collection, the techniques used are as follows:

\section{Observation}

Observations are made directly or indirectly. Direct observation is carried out by observing quality assurance management activities academic in increasing the absorption of graduates in SMKN 9 and SMKN 13 Bandung. Aspects observed are quality assurance management activities that include planning, implementation, monitoring and evaluation and remedial actions to improve academic quality and graduate absorption, including: 1) Preparation of Work Plan and School Budget, 2) Implementation of cooperation with partner agencies through prakerin program. 2) Availability of laboratories and practicum tools of each competency of expertise in accordance with industry standards, 3) Management of Special Job Exchange, 4) Implementation of business units/teaching factory, 5) Labor demand from the business and industrial world, 6) Follow-up school quality management for improvement and quality improvement. While observation is indirectly done by observing data and documentation in the field. Observation is focused on how academic quality assurance management activities in increasing the absorption of graduates. As affirmed by Satori and Komariah (2010:105); "Observation is the observation of an object that is studied either directly or indirectly to obtain data that must be collected in the study. For the purposes of this research, the object of observation carried out includes social situations consisting of places, actors and activities" 


\section{a) Interview}

The interview was conducted through direct dialogue with the Principal, Deputy Principal, School Quality Assurance Team, Teachers, and students of State Vocational High School 9 as well as at State Vocational High School 13 Bandung City. In this case the interview was conducted in an unstructured manner, where the respondent gained the freedom and opportunity to express thoughts, views, and feelings naturally and factually.

Some of the questions asked to the School, Deputy principal of curriculum, deputy principal of public relations, coordinator of Quality Management System, are related to how the implementation of academic quality assurance management focused on Deming cycle quality assurance management activities known as PDCA cycles. Interview questions broadly include who plans (Plan) academic quality assurance, how to implement it (Do), why it needs to be done monitoring and evaluation (Check), follow-up (Action) what quality assurance management does on the results of monitoring and evaluation obtained, how the availability of graduates in the business world and the industrial world, what obstacles the team faces. Quality Assurance of the school and how the solution. The interview conducted with the Coordinator of Special Job Exchange, Regional Business Services Agency, teachers and learners is related to how the implementation of prakerin, the implementation of teaching factory and the absorption level of graduates of SMKN 9 and SMKN 13 Bandung city in the business world and the industrial world.

\section{b) Documentation Studies}

Documentation studies are conducted by reviewing and processing document data that support aspects of academic quality assurance management. These types of documents include: 1) Quality policy documents (Standards of Education and school Quality Guidelines), 2) SOP Quality Improvement, 3) School Self-Evaluation Document, Quality Report card, National Education Standard Report card, 4) Industrial standard infrastructure facilities practicum inventory document, 5) MoU with partnership/partner agency, 6) SOP FieldWork Practices, 7) Teaching Factory Document, 8) Graduate certification documents, 9) Graduate availability documents in Business and industrial world from special job exchanges, 10) Academic quality audit documents, 11) Academic supervision documents, 12) Quality fulfillment reports, 13) Monitoring and evaluation reports, 14) Follow-up reports of monev results and others.

In this study, researchers at once became instruments or research tools. In order for researchers to account for the validity of the data obtained, the researcher prepares a research grid instrument. The research grid contains variables or aspects that will be collected data, data sources, observation guidelines, interview guidelines and documentation study guidelines for triangulation needs. As Sukmadinata (2009:235) directives that: "Before the writing instrument is composed, it is necessary to make a grid of such instruments. The grid of instrument preparation contains at least three components, namely variables or aspects to be measured /collected data, data collection techniques and data sources or respondents. To facilitate in the field, researchers arrange a grid of research instruments, observations, interviews, and documentation studies. The grille as a material for the preparation of research instruments. The writing grid can be seen in the attachment section."

This research was conducted at two State Vocational High Schools in Bandung, namely SMKN 9 and SMKN 13 Bandung City. The subjects in this study are the Principal, Deputy Principal, Quality Assurance Team, Teachers, Business Arrangements Staff and students at SMKN 9 and SMKN 13 Bandung.

In determining the research subjects, the author uses purposive sampling technique, which is a data source sampling technique with certain considerations. The author determines the sample to be used as a key informant with consideration of the importance of extracting data directly from the data source or key informant who knows the data and information related 
to the research variable. As Burhan Bungin (2012:53) directs, "in the most important sampling procedure is how to determine a key informant or a specific information-laden social situation. Choosing a sample, in this case a key informant or social situation is more appropriately done intentionally or purposefully, namely by purposive sampling"

The research data source was selected using perspectif emic, meaning that it attaches importance to the views of informants, namely how they perceive and interpret the world from their stance. In this case, the researcher cannot force his will to obtain the desired data. In accordance with the focus of this research, the data source is the standard learning process and the quality standards of graduates, Quality Management System teams involved in academic quality assurance activities, Special Work Team, teachers, students and principals.

Data analysis is done with qualitative techniques. This technique produces data that is descriptive and not in the form of numbers. In the use of qualitative analysis, interpretation of what is found and final conclusions using logic or systematic reasoning. Qualitative analysis used is an interactive analysis model, which is an analysis model that requires three components in the form of data reduction, data presentation, and conclusion /verification withdrawal using the Sugiyono interactive model (2012: 154).

\section{RESULTS AND DISCUSSION}

Based on the findings of the study it can be known that the management of academic quality assurance in increasing the absorption of graduates in SMKN 9 and SMKN 13 Bandung has been implemented, but in its implementation is still the fulfillment of the school's administrative obligations. School quality assurance has not been implemented continuously, integratedly and synergistically. As Deming in Nasution (2010:132), states that,"PDCA (Plan, Do, Check, Action) is a continuous improvement model developed to connect operations with customer needs and focus resources all within the company in an integrated and synergistic manner to meet customer needs.

Based on the findings of research and theoretical studies that underlie this study, the results of the study as described in the following image:

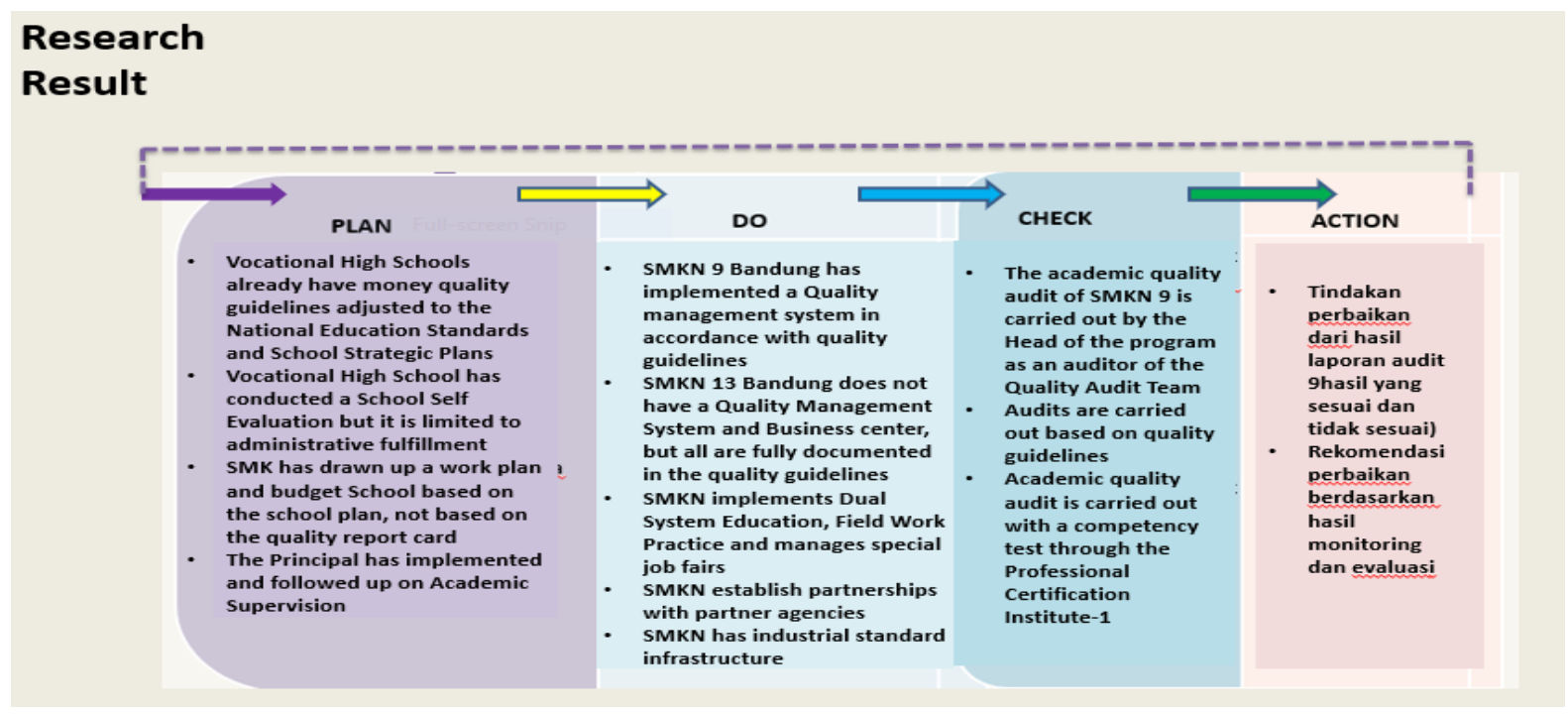

Figure 1. Vocational School Academic Quality Assurance Management Cycle Source: Fitriyani Kosasih, (2022). Dissertation. Academic Quality Assurance Management To increase the Absorption of Vocational Graduates 
Based on the picture it can be explained that the results of this study are:

1. At the Planning Stage (Plan), State Vocational High School has carried out academic quality planning activities but in implementation is still not optimal. This is proven by; 1) it has established a Quality Guideline that refers to the fulfillment of the National Standard of Education, SPMI (ISO 9001:2015) and is adjusted to the school Plan, 2) it conducts School Self-Evaluation but is limited to the fulfillment of school administration. 3) The new Work Plan and School Budget based on the School Plan, not based on the results of School Self-Evaluation and National Standards of Education Achievement. The preparation of Work Plan and School Budget is carried out in a school coordination meeting, which is held at the end of each year of study. Work Plan and School Budget is structured by involving principals, teachers, Administrative staff, and school committees. 4) The Principal has carried out academic supervision including planning activities, implementation, evaluation and follow-up of academic supervision.

2. At the Implementation Stage (Do), academic quality assurance in Vocational School has been broadly in accordance with planning procedures, referring to the quality policy of implementation of the internal quality assurance system at the high school/Vocational School level and there is a priority scale of quality fulfillment programs both in the management of institutions and in the learning process, but there are still state vocational schools that do not have a Quality Management System Team. The person in charge of the Quality Management System Team is the Principal. The time frame for the implementation of quality fulfillment activities is one year. In the fulfillment of school quality involving supervisors, principals, teachers, students, school committees, education personnel, College, Business and Industry, the School's regional government compiled a document on the results of quality fulfillment implementation. The school has set a priority scale based on the results of school quality mapping (School Self-Evaluation and quality report card), availability of resources, level of fulfillment needs, time period needed, and budget needs which are then poured into the School Work and Budget Plan. Some of the priority scales of academic quality fulfillment of state vocational graduates include State Vocational High School establishing partnerships with partner industries according to competence of expertise, having a infrastructure of learning quality support practices such as practicum rooms and laboratories in accordance with areas of expertise adapted to industry standards, managing a Special Job Exchange, that aims to provide job information services, marketing implementation, distribution, and personnel placement. Vocational graduates work, organize production units/business centers/technopark industry standards, and carry out student fieldwork practices in the world of work.

3. In the Monitoring and Evaluation (Check) Stage, monitoring and evaluation in State Vocational High School has been implemented but not optimal. This is evidenced by the existence of State Vocational High School which does not have an Quality Management System, so that quality audit activities are not carried out procedurally by auditors from the Quality Management System. In there which has an Quality Management System, monitoring and evaluation activities of academic quality assurance are carried out by the Head of Program as part of the auditor of the Quality Management System Team. Head of Program will audit and make an audit report. Audits are conducted on the competence of graduate expertise to assess the conformity between the process and the results of the training. The type of academic assessment in vocational school consists of repeats, school exams, National Exams, Competency Unit Examination, and Competency Examination of Expertise. The audit report shows the ability of the school's quality goals. In this report, it can be known the level of achievement of quality targets that have been planned through 
the Work Plan and School Budget based on School Self-Evaluation and some quality goals that have not been achieved, as well as recommendations for improvement. The report of the results of this audit, will be used to compile new quality goals in the next school year. So that there will be continuous quality improvement (continously improvement).

4. In the Remedial/Follow-up Action Stage, it has drafted remedial actions in an effort to increase graduate absorption. This is strengthened by the strategic actions that are poured into the Work Plan and School Budget and made based on the results of monitoring and evaluation. Broadly speaking, it arranges a strategic program into two parts, namely First, Continuous improvement action consisting of: 1) Action on the results of inappropriate training 2) Quality Fulfillment Improvement Program for the appropriate training results. Second, follow-up on the results of academic supervision to teachers on an ongoing basis.

5. Graduate Absorption. The percentage of state vocational graduates who get a job within one year after graduation only reaches $50 \%$. The low achievement of the graduate uptake partnership component by the world of work is allegedly caused also by the low number of other components that should be integrated, including: 1) The low achievement of fieldwork practices is one of which is caused by first, the high number of vocational schools that are still in the process of developing networks with Business and industrial world compared to the number of vocational schools that already have a network of work. Second, the low scholarship budget, donations in the form of leveling support for industrystandard learning. Third, the low number and role of teachers/instructors from industry and experts from the world of work (not reaching 50 hours/semeste /expertise program), 2) Low learning based on Real Project from the World of Work (PjBL). PjBL aims to ensure a balance between hardskills, softskills and strong student character so that graduates are ready to enter the workforce, 3) Low applied research and the implementation of teaching factories based on industry needs and the results can be marketed to industry and market, 4) Low application of curricular compiled with industrial, including strengthening Soft Skills and character of work to complement hardskills that suit the needs of the world of work. 5) Low technology update and training for teachers/instructors regularly in the world of work, 6) Low competency certification in accordance with the standards and needs of the world of work (For graduates and for teachers/instructors)

Based on these constraints, the solutions to overcome them are: 1) The Head of vocationally and the Quality Assurance Team of the Education Unit is given strengthening to implement a quality assurance system model that is easy to understand and apply so that Vocational School can implement a quality assurance system correctly, systematically and continuously. 2) Optimizing partnerships with partner agencies to establish work networks. 3) Organize a Teaching factory based on industrial needs and the results can be marketed to industry and markets. 4) Optimization of programs from Regional Business Service Entities by revitalizing Vocational School as a whole. From the provision of laboratory buildings, practice rooms and also practical equipment to the revitalization of the curriculum based on industrial needs. So that the vocational curriculum is no longer supply based, but demand based, which is a demand-based (industrial) curriculum" 5) Provide opportunities for graduates and teachers to get Competency certification in accordance with the standards and needs of the world of work. Based on the results of the study, the hypothetical model of this study is the Academic Quality Assurance Management Model in Increasing the Absorption of Vocational Graduates described below: 




Figure 2. Academic Quality Assurance Management Model in Improving the Absorption of VOCATIONAL Graduates

Source: Fitriyani Kosasih, (2022). Dissertation. Academic Quality Assurance

\section{Management}

To increase the Absorption of Vocational Graduates

Based on the picture, it can be explained that the absorption of graduates can be improved by improving the academic quality of graduates through the implementation of the PDCA cycle in a planned, systematic and sustainable manner by involving the community, stakeholders and Industry. The steps of the PDCA quality assurance cycle include;

1. Quality improvement planning. Starting with quality mapping activities based on the results of School Self-Evaluation and National Standards of Education. Continued by drafting a Work Plan and School Budget

2. Implementation of quality fulfillment, both in the management and learning process. Management includes activities to manage human resources, infrastructure facilities, academic services, finance, partnerships. The Link and Match Curriculum includes; 1) The curriculum is co-organized and standardized by the Business and Industrial World, 2) Real Project-based Learning (PjBL), 3) Teachers from the industry teach at least 50 hours per semester per area of expertise. 4) Industrial work practices/internships for at least one semester, 5) Graduates have certificates of competence, 6) Routine training of teachers by The World of Business and Industries, 7) Applied research with the business and industrial world (Teaching Factory), 8) uptake commitment by the world of business and industry and scholarships or service ties from the business and industry for vocational education.

3. Monitoring and evaluation (monev) of the quality fulfillment process that has been done to see the conformity between the process and the results of the training. Monev activities are carried out by conducting audits on student competency tests. Audit conducted by the Head of Program as a quality auditor

Quality improvement actions implemented by establishing 1) new standar and developing quality improvement strategies based on monitoring and evaluation results. 2) Follow-up on academic supervision results 


\section{CONCLUSION}

Based on the success of quality assurance by the education unit in the Instruction for the Implementation of Quality Assurance of Education in 2017, the general conclusion of this research is that in principle State Vocational High School has implemented a quality management system but has not succeeded. This is in the book with the output that shows the organization of the quality assurance system in schools has not functioned as it should, so that the education unit has not implemented an integrated quality assurance system, synergy and continuity. Outcome education unit shows that the learning and management process has not fully run according to standards, so the quality culture has not been built and has an impact on the improvement of the quality of learning outcomes in the last three years.

\section{REFERENCES}

Fattah, Nanang, (2012). Sistem penjaminan mutu pendidikan. Bandung: PT Remaja Rosdakarya.

Kosasih, Fitriyani (2022). Disertasi Manajemen Penjaminan Mutu Akademik Untuk Meningkatkan Daya Serap Lulusan SMK

Nasution, M. N. (2010). Manajemen Mutu Terpadu (Total Quality Management). Jakarta: Ghalia Indonesia

Sallis, Edward. (2011). Total Quality Management in Edecation: Manajemen Mutu Pendidikan. Alih Bahasa Ali Riyadi, Ahmad \& Fahrurozi. Irchisod, Yogyakarta, hlm 73.

Sani, Ridwan Abdullah, (2015). Sistem Penjaminan Mutu Pendidikan. Jakarra: Bumi Aksara

Saputra, Suhar, (2007). Konsep Penjaminan Mutu. Bandung:Remaja Rosdakarya.

Satori, Djam'an \& Komariah, Aan (2010). Supervisi Akademik Pengawas. (Teori dan Aplikasi Melalui Mutu Pendidikan)". Jakarta: Rhineka Cipta

Sugiyono, (2012). Metode Penelitian Bisnis (Pendekatan Kuantitatif, Kualitatif, Dan R\&D), Alfabeta, Bandung, hlm. 398-399.

Sukmadinata, Nana Syaodih,(2009). Metode Penelitian Pendidikan. Bandung: Remaja Rosdakarya.

Yin, Robert K. (2013). Studi Kasus Desain dan Metode. Jakarta: PT. Raja Grafindo. Persada. 